31. Johnston, H., Whitten, G. \& Birks, J. J. geophys. Res. 78, 6107-6135 (1973).

32. Zeldovich, Ya. B. \& Raizer, Ya. Physics of Shock Waves and High Temperature Phenomena Vol. 2, 566-571 (Academic, New York, 1967).

33. Chameides, W. L. Nature 277, 123-125 (1977). 215-221 (1982)

35. Park, C. Acta astronautica 5, 523-542 (1978).

36. Cicerone, R. J. \& Zellner, R. J. geophys. Res. 88, 10, 689-10, 696 (1983)

37. Giorgi, F. \& Chameides, W. L. J. geophys. Res. 90, 7872-7880 (1985).

38. Lowe, D. C. \& Schmidt, U. J. geophys. Res. 88, 10, 844-10, 858 (1983).

\section{Direct conversion of methane to methanol, chloromethane and dichloromethane at room temperature}

\section{Kotaro Ogura \& Kenji Takamagari}

Department of Applied Chemistry, Yamaguchi University, Ube 755, Japan

As methane is extremely inert, its conversion into a form suitable for chemical use has been achieved by an indirect process in which methane is first converted to synthesis gas and then to methanol and to ethylene glycol ${ }^{1}$. One disadvantage of this route of conversion is that it requires conditions of high temperature and pressure ${ }^{2}$. Here we report the direct conversion of methane to methanol, chloromethane and dichloromethane at the three-phase interface (gas/solution/electrode) on illumination at room temperature. The key steps in this process are: (1) electrochemical oxidation of the chloride ion; (2) generation of the chlorine radical under illumination; and (3) formation of the methyl radical by the reaction of methane with the chlorine radical.

In the present study, we attempted the combined photochemical and electrochemical oxidation of methane at room temperature. A conventional two-compartment glass electrolysis cell was used, with the anode compartment separated from the cathode compartment by a fritted-glass partition. A water-sealed stopcock and a Luggin capillary provided contact between the anode and the reference electrode. The anode compartment incorporated a flat quartz window through which we illuminated the cell, using as a light source a 4-W low-pressure mercury lamp (Hamamatsu TV, L937-04). The wavelength of the illumination was $254 \mathrm{~nm}$. The anode comprised a platinum plate partially immersed in the anolyte, and methane was introduced above the level of the solution. Only the surface of the platinum exposed to the gas phase was illuminated. To collect volatile products, the effluent gas was passed through a trap $\left(25 \mathrm{~cm}^{3}\right)$ containing $20 \% \mathrm{KOH}$ by weight. Both the electrolytic solution and the trap were kept at $25 \pm 1{ }^{\circ} \mathrm{C}$. Various strengths of $\mathrm{KCl}$ solution were used as electrolytes; the results presented here are for a $0.6 \mathrm{M} \mathrm{KCl}$ solution of $p \mathrm{H} 11.0$.

We determined the oxidation products present in both the electrolyte and residues in the trap by steam chromatography using an Ohkura Model SSC-1 which uses steam as the carrier gas and incorporates a flame ionization detector (FID) and a Poropak $\mathrm{R}$ column. This equipment is capable of detecting directly organic substances dissolved in an aqueous solution, without any pretreatment ${ }^{3}$.

The steam chromatograms of the solution after electrolysis at potentials more positive than $+1.3 \mathrm{~V}$ (compared with the standard calomel electrode, SCE) showed four peaks at 2.0, 3.3, 10.0 and $26.1 \mathrm{~min}$ corresponding to chloromethane, methanol, dichloromethane and trichloromethane, respectively. However, the peak due to trichloromethane was very small compared with the other three peaks. No such peaks were observed for the solution electrolysed in the dark.

Table 1 shows the amounts of $\mathrm{CH}_{3} \mathrm{Cl}, \mathrm{CH}_{3} \mathrm{OH}, \mathrm{CH}_{2} \mathrm{Cl}_{2}$ and $\mathrm{CHCl}_{3}$ produced in the $0.6 \mathrm{M} \mathrm{KCl}$ solution at $p \mathrm{H} 11.0$ for various anodizing potentials. At potentials more negative than $+1.0 \mathrm{~V}$, there was no oxidation of methane. Conversion to $\mathrm{CHCl}_{3}$ and
Table 1 Yield of chloromethane, methanol, dichloromethane and trichloromethane in a $0.6 \mathrm{M} \mathrm{KCl}$ solution at $p \mathrm{H} 11.0$

\begin{tabular}{crccc}
\hline$V_{\mathrm{e}}(\mathrm{V})$ & $\mathrm{CH}_{3} \mathrm{Cl}$ & $\mathrm{CH}_{3} \mathrm{OH}$ & $\mathrm{CH}_{2} \mathrm{Cl}_{2}$ & $\mathrm{CHCl}_{3}$ \\
1.1 & 0.4 & 0.2 & 0.0 & 0.0 \\
1.2 & 15.3 & 0.8 & 0.0 & 0.0 \\
1.3 & 24.9 & 6.1 & 9.6 & 0.3 \\
1.4 & 164.3 & 6.3 & 16.7 & 0.3 \\
1.5 & 239.9 & 10.5 & 17.9 & 0.9 \\
1.6 & 18.1 & 1.1 & 0.2 & 0.0 \\
1.7 & 29.3 & 1.9 & 0.4 & 0.0 \\
1.8 & 59.6 & 2.9 & 1.6 & 0.1 \\
1.9 & 95.1 & 6.6 & 6.4 & 0.3 \\
2.0 & 95.8 & 7.4 & 8.6 & 0.7 \\
\hline
\end{tabular}

$V_{e}$, electrolysis potential compared with the saturated calomel electrode. Values shown are the quantities (in $\mu \mathrm{mol}$ ) of electrolysis products. Electrolysis time was $3 \mathrm{~h}$; volume of electrolyte $20 \mathrm{~cm}^{3}$; the anode comprised a platinum plate of area $6 \mathrm{~cm}^{2}$.

$\mathrm{CH}_{3} \mathrm{OH}$ commenced at $+1.1 \mathrm{~V}$, and further conversion to $\mathrm{CH}_{2} \mathrm{Cl}_{2}$ and $\mathrm{CHCl}_{3}$ began at $+1.3 \mathrm{~V}$. At $+1.5 \mathrm{~V}$, the formation of these compounds was at a maximum, the current efficiencies being $12.8 \%\left(\mathrm{CH}_{3} \mathrm{Cl}\right), 0.38 \%\left(\mathrm{CH}_{3} \mathrm{OH}\right)$ and $2.05 \%\left(\mathrm{CH}_{2} \mathrm{Cl}_{2}\right)$ where the electric charge passed was $361.7 \mathrm{C}$. Chemical and gas-chromatographic analyses were done to detect other species such as $\mathrm{HCHO}$ or $\mathrm{CO}_{2}$; however, the results were negative.

The results presented here indicate that the electrochemical evolution of the chlorine molecule and the formation of its radical on illumination are prerequisites for triggering the activation of methane. The photochemical chlorination of methane is well understood. Mixtures of methane and chlorine react rapidly in the presence of light. However, for this reaction to occur, the two gases must be mixed at an appropriate ratio, and the reaction is difficult to control as hydrogen atoms are replaced by chlorine atoms almost at random. In the combined photochemical/electrochemical method described here, the chlorination can be stopped after the initial stage because the formation of the products is a function of the electrode potential. Another feature of this method is that methane is converted directly to methanol. The formation of methanol may be explained in two ways. First, by the further oxidation of the methyl radical by electrolytic catalysis:

$$
\begin{gathered}
\mathrm{M}(\text { electrode })+\mathrm{H}_{2} \mathrm{O} \rightarrow \mathrm{MOH}+\mathrm{H}^{+}+\mathrm{e}^{-} \\
\mathrm{MOH}+\cdot \mathrm{CH}_{3} \rightarrow \mathrm{CH}_{3} \mathrm{OH}+\mathrm{M}
\end{gathered}
$$

where $\mathrm{MOH}$ is the intermediate species in the electrochemical evolution of oxygen ${ }^{4}$. The second explanation involves hydrolysis of $\mathrm{CH}_{3} \mathrm{Cl}$ :

$$
\mathrm{CH}_{3} \mathrm{Cl}+\mathrm{OH}^{-} \rightleftharpoons \mathrm{CH}_{3} \mathrm{OH}+\mathrm{Cl}^{-}
$$

Reaction (1) is endoergic, and reaction (3) seems to predominate. In fact, the formation of methanol was more favourable at higher $p \mathrm{H}$. However, reactions (1) and (2) must occur because methanol was produced even in strongly acidic solution $(p \mathrm{H} 1)$. We are presently studying the mechanism in detail. The rather complicated effect of the anodizing potential on the formation of the electrolytic products may be related to the evolution of oxygen-that is, an oxygen or hydroxyl radical generated during anodization could act as a scavenger for chlorine and methyl radicals. That the most important step in this conversion process is the radical reaction in the gas phase is demonstrated by the very small amounts of the products yielded when a methanesaturated solution was used, but the electrode was completely immersed (the light then passing through the solution).

Received 12 August; accepted 7 November 1985.

\footnotetext{
1. Hatch, L. F. \& Matar, S. From Hydrocarbons to Petrochemicals 58-61 (Gulf Publishing Company, Houston, 1981).

2. Kuhre, C. J. \& Shearer, C. J. Oil Gas J. 85-90 (1971).

3. Nonaka, A. Analyt. Chem. 44, 271-276 (1972).
}

4. Bockris, J. O'M. J. chem. Phys. 24, 817-825 (1956) 